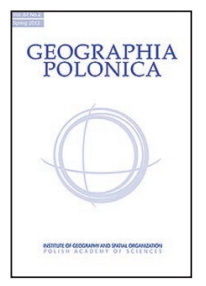

\author{
APAN \\ INSTITUTE OF GEOGRAPHY AND SPATIAL ORGANIZATION \\ POLISH ACADEMY OF SCIENCES \\ www.igipz.pan.pl \\ www.geographiapolonica.pl
}

\title{
RELATIONS OF GEOGRAPHY WITH OTHER DISCIPLINES: A BIBLIOMETRIC ANALYSIS
}

\author{
Krzysztof Stachowiak • Artur Bajerski \\ Institute of Socio-Economic Geography and Spatial Management \\ Adam Mickiewicz University in Poznań \\ Dzięgielowa 2, 61-680 Poznań: Poland \\ e-mails: krst@amu.edu.pl・bajerski@amu.edu.pl
}

\begin{abstract}
The aim of this article was to examine the relations of physical and human geography with selected disciplines of natural and exact sciences as well as social sciences. The results shows that: (1) the position of geography among other disciplines is relatively high, however the relative position of human geography in social sciences is higher than that of physical geography in natural and exact sciences, (2) both geographical disciplines show an adverse 'trade balance' in scientific exchange, (3) human geography is more 'introverted', (4) relations between human geography and other disciplines are stronger than in the case of physical geography.
\end{abstract}

\section{Key words}

geography $\bullet$ bibliometric analysis $\bullet$ journals $・$ citations

\section{Introduction}

Relations of geography with other disciplines are often used to assess the operation of geography as an independent science (Turner 2002; Mulligan 2003; Lisowski 2004). Some researchers stress the weakness of geography resulting, among other things, from borrowing scientific knowledge from other fields (e.g. Mulligan 2003; Lisowski 2004). Others, in turn, claim that the weakness of geography is rather a result of its insufficient integration with other disciplines and reliance primarily on its own output
(Ferguson 2003). Often, especially in Polish geography, the problem discussed is that of its poor internal integration, i.e. cooperation between physical and human geography, and the low position of geography in the science system and in practice (Lisowski 2008, 2011; Maik 2008; Richling 2008; Bański 2010, 2013).

The quantitative analyses of relations of geography with other disciplines made so far have focused primarily on Anglo-Saxon geography and involved comparing publication practices of physical and human geographers. With reference to young scholars, Thrift 
(2002) reports that human geographers publish almost exclusively in journals representing their subdiscipline. The differences in the publication practices of researchers representing the two subdisciplines of geography were later corroborated by Ferguson (2003) and Johnston (2005). When examining publication practices of physical and human geographers, Ferguson (2003) analysed in what journals selected eminent scholars published their most influential works (with more than 20 citations in the Web of Science database). He found that physical geographers tended to publish in interdisciplinary journals decidedly more frequently than human geographers. This was confirmed by Johnston's (2005) study of British geography. On the basis of information given by geographical units for a parametric assessment of their scientific activity in 2001 (the so-called RAE, or Research Assessment Exercise), he showed that British human geographers published primarily in British geographical journals, while British physical geographers did so mainly in American interdisciplinary journals. Ferguson's (2003) and Johnston's (2005) results can provide a basis for the thesis that physical geography is more closely connected with natural sciences than human geography is with social sciences (Lisowski 2011), which can imply that physical geography occupies a higher position in the system of sciences. It should be kept in mind, however, that this situation may change in successive years. This is suggested by the results of a study by Foster et al. (2007), who demonstrated a growing share of important (i.e. highly cited) works by economic geographers in non-geographical journals after 1980.

Differences in publication practices between physical and human geographers are not limited to publication in different kinds of journals, but also involve a broader problem: the share of various scientific communication media. Ferguson (2003) explains the greater number of highly cited works in the output of eminent physical geographers, among other things, by the lesser significance of monographs in physical geography than in human geography, for which they are the chief medium for reporting the results of scholarly work in some countries (e.g. Ward et al. 2009; Bajerski \& Siwek 2011).

These studies of publication practices of geographers, although valuable in cognitive terms, show the links of geography with other sciences only in an indirect way. In fact, they concern modes of scientific communication. However, relations among disciplines manifest themselves in the use of scientific knowledge and research methods (Chojnicki 1999: 93). Hence a direct picture of those relations can be obtained by analysing the use of geographical knowledge and methods in other disciplines and the use of knowledge and methods of other disciplines in geography. Such studies can be qualitative in nature, e.g. when the scope and significance of links is assessed on the basis of selected cases, or quantitative, when an analysis is made of the citation rates of works. Especially wide possibilities are offered by a quantitative analysis of citations; it allows covering a large number of articles and journals while reducing the arbitrariness of decisions taken in the course of the research procedure.

In spite of the advantages of an analysis of citations in the assessment of the links of geography with other sciences, only a few authors have used this method so far. One of the first analyses of the problems at hand was presented by Whitehand (1985), who focused on whether works authored by the group of the most often cited geographers were cited primarily by geographers, or also by representatives of other disciplines (without their identification). His study showed a comparable proportion of citations from geography and other disciplines, with citations by geographers dominating in the earlier years of their scholarly careers, and citations by representatives of other disciplines, in their later years.

The use of publications from physical and human geography by other disciplines was examined in the next years by Bodman (1991). He analysed citation rates of works authored by a large group of geographers 
working at universities in Great Britain, the United States, Canada and Australia, holding posts corresponding to those of a lecturer or assistant professor, and higher. His study showed human geography to be much more 'introvert' than physical geography. Social and economic geographers were almost twice as often cited in key geographical journals as physical geographers (39\% and 20\% of all citations, respectively), and almost half as often in key journals of other disciplines (15\% and $30 \%$, respectively). This higher 'introversion' of human geography revealed by Bodman (1991) has been corroborated by Foster et al. (2007) and Laffan (2010). Foster et al. (2007) showed that the most frequently cited articles in economic geography, almost without change from the 1980s to the start of the 21st century, were those quoted in geographical journals (ca. 50-55\% of all citations). Less frequently geographers' works were cited in journals representing environmental sciences (ca. 30\%), urban studies (ca. $17 \%$ ), and economy (ca. 12\%). The use of the results of economic geography works in sociology, political science and management (up to $5 \%$ ) was marginal, although growing.

In turn, Laffan (2010), in what might be the fullest quantitative study of the relations of geography with other disciplines based on an analysis of citations from the Web of Science, demonstrated that the 'introversion' level of human geography was one of the highest in the set of the 34 scientific disciplines he analysed (5th place). He calculated that the 'introversion' of human geography was 3.2 times higher than of physical geography, and showed that both geographical subdisciplines were more strongly connected with other disciplines than with each other.

Since the question of links of geography with other disciplines is still poorly understood, this article offers a quantitative look at this problem which is an extension of Laffan's (2010) research. The chief goal was to examine the strength of links of physical and human geography with selected disciplines of exact and natural sciences on the one hand and with social sciences on the other. The measure of the links was the number of citations of articles from geographical journals in those representing other disciplines and vice versa. More specifically, the article sought: (1) to determine the position of geography among related disciplines, (2) to identify disciplines most strongly associated with geography by an exchange of scientific information, (3) to determine the relations of knowledge import/export between human geography, physical geography and other disciplines, and (4) to determine the average strength of the links of human and physical geography with exact and natural sciences as well as social sciences.

What should be kept in mind is that this article, like the research results mentioned above, refers to so-called international geography. International geography, referred to in the text simply as geography, is assumed to be this part of results that are published in journals indexed by Thomson Reuters in the Web of Science database (although the application of the term 'international' to geography understood in this way arouses justified criticism because of its being dominated by Anglo-American researchers, journals and theories - see, e.g., Minca 2000, Guttiérrez \& López-Nieva 2001; Short et al. 2001; Yeung 2001; Aalbers 2004; Simonsen 2004; Timár 2004; Aalbers \& Rossi 2006, 2009; Bański \& Ferenc 2013). The authors of this article are aware that in fact international geography is a resultant of diverse publication practices of scholars from a variety of regions and countries, which should also be a subject of separate studies (Schuermans et al. 2010; Bajerski 2011; Bajerski \& Siwek 2012).

\section{Chief sources of information about citations}

In this study the relations of geography with other sciences were examined by analysing citations of articles published in geographical journals and those representing other disciplines science. At the initial stage of the research procedure an assessment was made 
of possibilities offered by three citation bases most popular today: Web of Science, Scopus and Google Scholar ${ }^{1}$. Their individual characteristics, advantages and defects as well as the comparability of the results obtained have often been discussed in scientific literature (Bar-llan 2008; Vieira \& Gomes 2009; Franceschet 2010; Mikki 2010; Mingers \& Lipitakis 2010). Those three citation bases have also been used in earlier studies concerning Polish geography. Racki (2003) and Bajerski (2008b) relied on the Web of Science database, Bajerski (2008a) used the Scopus database, while Śleszyński (2009, 2013a, 2013b, 2014) resorted to the Google Scholar database.

The only citation database among those employed that allows an analysis of citations among disciplines is the Web of Science (cf. Tab. 1). In the Scopus database, journals are assigned to very generally defined fields of science (e.g. social sciences and the humanities, natural sciences), while Google Scholar does not make such an analysis possible at all. That is why in the research use was made of the Web of Science database.

The Web of Science is the oldest and most prestigious multi-field scientific citation database in the world. In 2011 it had more than 46 million indexed articles representing all fields of science. It had seven citation bases:

1. the Science Citation Index Expanded (SCIE), which indexes over 8.3 thous. journals from exact, natural and technical sciences, the oldest articles coming from 1900;

2 the Social Sciences Citation Index (SSCI), which indexes over 4.5 thous. journals from social sciences, the oldest articles coming from 1900;

3. the Arts \& Humanities Citation Index $(\mathrm{AHCl})$, which indexes over 2,3 thous. humanities journals, the oldest articles coming from 1975;

\footnotetext{
${ }^{1}$ Google Scholar indexes scientific articles like typical scientific databases, but in principle it is a freely accessible Web search engine.
}

4. the Conference Proceedings Citation Index, which indexes conference materials from over 148 thous. conferences, including 12 thous. taking place every year; the oldest articles come from 1990;

5. Index Chemicus, which indexes articles from over 100 chemical journals and provides information about more than 2.6 chemical compounds; and

6. Current Chemical Reactions, which provides information about more than a million chemical reactions.

7. Book Citation Index, which indexes editorially selected books.

The most relevant for bibliometric purposes are the first three bases, i.e. the Science Citation Index Expanded (SCIE), the Social Sciences Citation Index (SSCl), and the Arts \& Humanities Citation Index (AHCl). Together they provide information about more than 47 million scientific articles published in over 12 thous. journals. It should be kept in mind that this number is smaller than the sum of journals indexed in each of the bases discussed, because often a journal is indexed in two, and even all three of them. This holds, e.g., for general geographical journals publishing articles from both, natural and social sciences. The Web of Science database rests on a selected set of scientific journals embracing key periodicals in the given disciplines in the world. The decision to include a journal into one of those bases is preceded by a rigorous procedure in which such things are considered as punctual publication of its successive volumes, the international position of its authors and editorial board, and citation rates of articles published in it.

Most journals in the Web of Science database (ca. 65\%, Tab. 1) come out in the United States, which leads to frequent criticism and accusations of 'Americentrism'. This at least a decade-long criticism of bases of the Web of Science and the Thomson Reuters corporation (Yitzhaki 1998; Archambault et al. 2006; Hassink 2007) has led to their opening to journals from regions and countries so far under-represented (e.g. Asia, South America, Africa, or East-Central Europe, 
Table 1. Basic information about the three most popular citation bases: Web of Science, Scopus and Google Scholar in 2011

\begin{tabular}{|c|c|c|c|}
\hline Database characteristics & Web of Science & Scopus & Google Scholar \\
\hline Type & $\begin{array}{l}\text { database available } \\
\text { on-line }\end{array}$ & $\begin{array}{l}\text { database available } \\
\text { on-line }\end{array}$ & internet search engine \\
\hline Owner & Thompson Reuters & Elsevier & Google \\
\hline Paid subscription & yes & yes & no \\
\hline Launching year & $\begin{array}{l}1960 \\
\text { (Science Citation Index } \\
\text { Expanded) }\end{array}$ & 2002 & 2004 \\
\hline Number of indexed journals & ca. 12,000 & ca. 18,000 & not revealed by Google \\
\hline Number of indexed articles & 47 million & 40 million & not revealed by Google \\
\hline $\begin{array}{l}\text { Possibility of full analysis } \\
\text { of citations }\end{array}$ & 1945 onwards & 1996 onwards & $n / a$ \\
\hline Selectivity of journals & high & average & low \\
\hline$\%$ of journals published in USA & ca. $65 \%$ & ca. $45 \%$ & $n / a$ \\
\hline $\begin{array}{l}\text { Journals assigned to fields } \\
\text { of science (e.g. social sciences) }\end{array}$ & yes & yes & no \\
\hline $\begin{array}{l}\text { Journals assigned to disciplines } \\
\text { of science (e.g. geography) }\end{array}$ & yes & no & no \\
\hline
\end{tabular}

Source: own compilation on the basis of the Web of Science, Scopus and Google Scholar bases.

including Poland). As a result, a sudden jump can be observed, especially since 2007 , in the number of journals published in some countries, like Poland, Lithuania or Turkey. On the one hand, this has made the Web of Science database more representative of world science, and on the other, apart from strictly international periodicals, it now includes also those that are regional or local in range.
Each journal indexed in the Web of Science can be assigned to one or several disciplines (Tab. 2). Nearly $60 \%$ of journals are assigned to only one discipline, and $30 \%$ to two. The most multidisciplinary journals are entered in six disciplines at once. Journals from natural and exact sciences represent a few disciplines slightly more often than those from social sciences.

Table 2. Journals by the number of fields to which they are assigned in the Web of Science database

\begin{tabular}{|c|c|c|c|c|c|c|}
\hline \multirow{2}{*}{$\begin{array}{c}\text { Number of } \\
\text { disciplines } \\
\text { journal } \\
\text { is assigned to }\end{array}$} & \multicolumn{2}{|c|}{$\begin{array}{l}\text { Natural and exact sciences } \\
\text { (SCIE database) }\end{array}$} & \multicolumn{2}{|c|}{$\begin{array}{l}\text { Social sciences } \\
\text { (SSCl database) }\end{array}$} & \multicolumn{2}{|c|}{ Total } \\
\hline & $\begin{array}{l}\text { number } \\
\text { of journals }\end{array}$ & $\%$ & $\begin{array}{l}\text { number } \\
\text { of journals }\end{array}$ & $\%$ & $\begin{array}{l}\text { number } \\
\text { of journals }\end{array}$ & $\%$ \\
\hline 1 & 4,234 & 57.3 & 1,513 & 67.0 & 5,747 & 59.6 \\
\hline 2 & 2,271 & 30.7 & 648 & 28.7 & 2,919 & 30.3 \\
\hline 3 & 702 & 9.5 & 85 & 3.8 & 787 & 8.2 \\
\hline 4 & 152 & 2.1 & 10 & 0.4 & 162 & 1.7 \\
\hline 5 & 21 & 0.3 & 1 & 0.0 & 22 & 0.2 \\
\hline 6 & 7 & 0.1 & 0 & 0.0 & 7 & 0.1 \\
\hline Total & 7,387 & 100.0 & 2,257 & 100.0 & 9,644 & 100.0 \\
\hline
\end{tabular}

Note: The table lists journals with an established impact factor, hence the total number of journals in the table is smaller than the sum of all journals indexed in the Web of Science database.

Source: own compilation on the basis of the Web of Science and Journal Citation Report (2009). 


\section{Research method}

\section{Formulation of assumptions and operational definitions}

The basic assumption adopted in this study is that relations among disciplines can be established with the help of an analysis of citations. A citation is understood as an article from discipline $A$ referring to a work from discipline B. It was assumed that a citation meant the use of knowledge resources of a given discipline, irrespective of whether the reference was favourable or critical. Hence the basic index of the relation among disciplines is the number of articles that do the citing. This relation can be bi-directional, i.e. while being an object of influence itself, a scientific discipline also influences other disciplines. Hence the examination of links between geography and other disciplines also involved an analysis of citations by geography of works from other disciplines and an analysis of citations of geographical works by other disciplines.

Geography occupies a specific position in the system of sciences since it examines both, natural and social phenomena; hence the basic division of geography into physical and human. And those two disciplines were the core of the analysis: physical geography, which belongs to natural and exact sciences in the Web of Science database, and human geography, included among social sciences there. The period under study was the years 2006-2010, i.e. the analysis embraced works published then. The data were collected in the winter of 2012 and the analysis was made in the spring and summer of 2013.

\section{Choice of the disciplines examined}

Although the conception of a scientific discipline has its methodological model (Chojnicki 1999: 83-96), in this study a practical understanding of this term was adopted as a category distinguished in the Web of Science database. In 2009 the classification created for this database embraced 173 disciplines of natural and exact sciences and 55 disciplines of social sciences (so called Web of Sciences categories). While the classification and the names given to the disciplines may raise some objections, it should be observed that in the contemporary debate on science - in the situation of deep specialisation and intertwining fields of many disciplines - it has in fact a practical character. This is pointed out by philosophers of science who, like Bunge (1998: 27), claim that today "it would be foolish to place much emphasis on the problem of classifying the sciences, once a favourite pastime of philosophers and now a subject for science administrators and librarians". This is also the practical character of the classification adopted in the Web of Science database; it could be a subject of a separate study, hence it is not discussed in this article.

The choice of concrete disciplines was dictated by several reasons. First, the disciplines taken into consideration were primarily those with years-long history. They were also usually represented by the largest number of journals on the Web of Science. Secondly, the selection was also based on a previous research on the topic (e.g. Foster et al. 2007; Laffan 2010). As a result, data were obtained for the two fields of geography as well as for 26 other categories (13 from natural and exact sciences and 13 from social sciences) that either share journals or are expected to have some citation relationship with geography. Out of the natural and exact sciences, those selected for study included the following categories: astronomy and astrophysics, biology, chemistry, ecology, physics, geochemistry and geophysics, geology, soil science, informatics, mathematics, oceanography, palaeontology, and remote sensing. From the group of social sciences, the disciplines chosen were: demography, economy, history, management science, political sciences, pedagogy, planning, psychology, sociology, international relations, regional studies, transport, tourism and recreation. In the case of human geography, we used the JCR category called Geography, and for physical geography we used the 'Geography, physical' category. 
It is worth noting that although we used JCR categories as a substitute for disciplines, those two are not exactly the same. The allocation of journals to JCR categories is a heuristic process, as Pudovkin and Garfield (2002) explain. They note that "once the categories were established, new journals were assigned one at a time. Each decision was based upon a visual examination of all relevant citation data. As categories grew, subdivisions were established. Among other tools used to make individual journal assignments, the Hayne-Coulson algorithm is used. The algorithm has never been published. It treats any designated group of journals as one macrojournal and produces a combined printout of cited and citing journal data" (Pudovkin \& Garfield 2002: 1113). It means that there is some subjectivity in the allocation of journals to the categories. This is a possible problem for the present analysis in that the categories may not truly represent the diversity of the discipline of geography. However, as Laffan (2010: 168) points out, "the categories do appear to be logical groupings, journals can be indexed in more than one category, and the data do allow broad differences and relationships to be assessed".

\section{Choice of the research method}

Because of the assumption that relations among disciplines can be established through an analysis of citations, use was made of bibliometric methods, in particular of Pudovkin's index, known in bibliometrics and worked out in the 1990s. Detailed information and examples of its use can be found in Pudovkin (1993), Pudovkin and Fuseler (1995), and Pudovkin and Garfield (2002). This index is given by the formula:

$$
R_{\mathrm{AB}}=C I T_{\mathrm{AB}} /\left(C I T_{\mathrm{A}} \star A R T_{\mathrm{B}}\right) \star 10^{7}
$$

where:

$R_{\mathrm{AB}}$ - strength of the relation between disciplines A and B,

$C / T_{A B}$ - number of articles citing works from discipline $A$ in articles from discipline $B$,
$C / T_{A}$ - number of articles citing articles from discipline A,

$A R T_{\mathrm{B}}$ - number of published articles from discipline B.

The index assumes values from zero to infinity and is measured on a quotient scale, which makes the relations among its values reliable. It is relative in nature, i.e. the strength of a relation should be assessed by reference to other relations or to mean values. Its advantage is that it gives the number of citations between two disciplines examined in relation to the total citation count of a discipline. Also, it offers not only the absolute citation count, but also the volume of the scientific production of this discipline understood as the number of articles published by journals belonging to it. To illustrate the complex relations among disciplines, let us give the following example. In the years 2006-2010 human geography cited 573 articles from economy, and economy, 937 articles from human geography ${ }^{2}$ (cf. Tab. 4). This might imply that it was geography that supplied more knowledge to economy than the other way round. However, there were 37,187 articles published in economy over this time as against 9,552 of those in human geography. This means that, in a relative approach, $5.7 \%$ of geographical articles cited economy, and a mere $2.5 \%$ of economic articles cited geography. In turn, all geographical articles were cited by a total of 5,497 works, and economic papers by 19,659 articles. Hence the relation of the citations of geographical works by economy to all citations of geographical works is $0.10(573 / 5,497)$, and the proportion of citations of economic works by human geography to all citations of economic works is $0.05(937 / 19,659)$. It is

\footnotetext{
2 It should be kept in mind that formulations like 'human geography cited economy' are stylistic phrases intended to make the text more readable. What is meant here are articles in journals classified as belonging to the 'human geography' field in the Web of Science database whose authors cite works from journals belonging to the 'economy' field in this database. This remark also applies to the later text where this type of phrases appear as well.
} 
important to take into consideration those various aspects of the bi-directional relations between disciplines, and Pudovkin's index helps to model the complex links among disciplines in a simple way. For the geographyeconomy relation, this index amounts to 23.0, and for the economy-geography relation, 19.7. This means a slightly stronger relation of geography with economy than of economy with geography. This can be interpreted in terms of an exchange of goods in trade: human geography 'imports' a bit more goods from economy than it 'exports' to it. In Pudovkin's index the multiplier $10^{7}$ is established arbitrarily, its task being only to make the interpretation of results easier, because index values are very low. Thus, instead of 0.00000155 we get 15.5. This has no influence whatsoever on the variability of values or the results of analyses.

In the study use was also made of the impact factor of journals, which presents the frequency with which articles from a journal are cited over a specified time. In fact, this is an index of the general prestige and force of influence of scientific journals. It is calculated by the Institute for Scientific Information in Philadelphia as a simple quotient of two quantities:

$$
I F=X / Y,
$$

where:

$X \quad$ - is the total number of citations of all publications a journal received in a given calendar year that appeared in it over two the years preceding that year (without selfcitations), and

$Y \quad$ - is the number of all publications that appeared in that period. For example, if the index was 3 in 2010, this means that each publication that appeared in the journal in the years 2008-2009 was cited 3 times on average in 2010 by the authors of other publications in journals listed by the Institute for Scientific Information in Philadelphia. This index can assume values from zero to infinity, but in practice maximum values are ca. 30 for the most prestigious journals.

\section{Collecting and processing the data and their analysis}

The next stage involved collecting and processing data. As has already been mentioned, all information concerning citations comes from the Web of Science database. Citation counts were made for a total of 632,582 articles from 28 fields (2 geographical disciplines and 26 associated ones) and the material was further analysed using the methods described above. The basic part of the research procedure was an analysis of relations of the two geographical disciplines with other disciplines, the results of which are presented in a later part of this paper.

\section{Geography and other scientific disciplines}

The chief goals sought in the analysis of links of geography with other disciplines included: (a) establishing the position of geography among the disciplines examined, (b) defining the set of disciplines making most frequent use of geographical knowledge and the intensity of this use, (c) defining the set of disciplines from which geography derives knowledge and the intensity of this use, and (d) determining the strength of the relation between geography and the other disciplines.

The position of geography measured by the impact factor of scientific journals was relatively high (Tab. 3). Human geography came fourth among the 14 disciplines of social sciences examined, with the impact factor of 1.37, higher than for economy and sociology. In turn, physical geography occupied sixth position among the 14 disciplines of natural and exact sciences examined, with the impact factor of 2.29, higher than, e.g., in geology and palaeontology. It should be noted that an average article in physical geography had almost one citation more than an average article in human geography. In terms of the number of journals and published articles, geography came as a medium-sized discipline. In social sciences the biggest disciplines were economy, management 
science and political science, and in natural and exact sciences, physics, ecology and chemistry.

Because the position of the geographical disciplines with respect to the selected disciplines presented above could not match the actual position of geography, its place was checked relative to all disciplines entered in the Web of Science database. In terms of the impact factor, in 2009 human geography occupied 20th place among 55 disciplines of social sciences, and physical geography, 79th place among 173 disciplines of natural and exact sciences. Because the number of disciplines varies in natural and exact sciences, in order to compare the relative positions of the two disciplines their positions were normalised in the ranking (within the range of 0 to 100). This put human geography in the middle of the third decile (36th

Table 3. The position of geography among the examined disciplines in 2009

(a) Physical geography among the examined disciplines of natural sciences

\begin{tabular}{|c|c|c|c|c|}
\hline No. & Discipline & $\begin{array}{c}\text { Impact } \\
\text { factor average }\end{array}$ & $\begin{array}{l}\text { Number } \\
\text { of journals }\end{array}$ & $\begin{array}{l}\text { Number } \\
\text { of articles }\end{array}$ \\
\hline 1. & Astronomy and astrophysics & 4.44 & 53 & 14,562 \\
\hline 2. & Biology & 3.08 & 76 & 11,427 \\
\hline 3. & Physics & 2.89 & 71 & 21,998 \\
\hline 4. & Ecology & 2.78 & 129 & 14,289 \\
\hline 5. & Chemistry & 2.64 & 70 & 17,687 \\
\hline 6. & Physical geography & 2.29 & 36 & 3,420 \\
\hline 7. & $\begin{array}{l}\text { Geochemistry and } \\
\text { geophysics }\end{array}$ & 2.15 & 75 & 7,687 \\
\hline 8. & Oceanography & 1.90 & 56 & 4,950 \\
\hline 9. & Remote sensing & 1.73 & 21 & 1,934 \\
\hline 10. & Geology & 1.72 & 49 & 2,167 \\
\hline 11. & Soil science & 1.70 & 31 & 3,515 \\
\hline 12. & Palaeontology & 1.68 & 41 & 2,125 \\
\hline 13. & Informatics & 1.65 & 95 & 9,576 \\
\hline 14. & Mathematics & 1.55 & 80 & 6,737 \\
\hline
\end{tabular}

(b) Human geography among the examined disciplines of social sciences

\begin{tabular}{|c|c|c|c|c|}
\hline No. & Discipline & $\begin{array}{c}\text { Impact } \\
\text { factor average }\end{array}$ & $\begin{array}{l}\text { Number } \\
\text { of journals }\end{array}$ & $\begin{array}{l}\text { Number } \\
\text { of articles }\end{array}$ \\
\hline 1. & Psychology & 1.68 & 50 & 2,813 \\
\hline 2. & Management science & 1.65 & 112 & 4,932 \\
\hline 3. & Transport & 1.44 & 18 & 873 \\
\hline 4. & Human geography & 1.37 & 62 & 2,334 \\
\hline 5. & Tourism and recreation & 1.28 & 20 & 703 \\
\hline 6. & Economy & 1.15 & 247 & 11,856 \\
\hline 7. & Demography & 1.14 & 24 & 686 \\
\hline 8. & Planning and development & 1.05 & 44 & 1,860 \\
\hline 9. & Sociology & 0.92 & 114 & 3,581 \\
\hline 10. & Pedagogy & 0.88 & 139 & 5,339 \\
\hline 11. & International relations & 0.86 & 59 & 2,026 \\
\hline 12. & Political science & 0.81 & 112 & 4,259 \\
\hline 13. & Regional studies & 0.54 & 44 & 1,275 \\
\hline 14. & History & 0.36 & 32 & 726 \\
\hline
\end{tabular}

Source: own compilation on the basis of Journal Citation Report 2009. 
place), and physical geography, in the middle of the fourth decile (46th place). This shows the relative position of human geography among social sciences to be slightly higher than that of physical geography among natural and exact sciences.

One of the major aspects of relations of geography with other disciplines is determining the set of disciplines making most frequent use of geographical knowledge and the intensity of this use. This is done via an analysis of citations of works published in journals classed as geographical. For all articles in geography published in the years 2006-2010 , the number of articles citing them was examined and the disciplines they belonged to were identified. The results are presented in Tables $4 a$ and $5 a$. Works from physical geography were referred to by 13.5 thous. articles, and those from human geography were cited by 5.6 thous. articles. Slightly more than a half of works (54.0\%) citing physical geography came from three disciplines: ecology, physical geography and palaeontology. In human geography, a similar proportion of articles (52.8\%) were cited by four disciplines: human geography, ecology, economy, and planning. In the case of physical geography there was a greater 'concentration' of citations: the ten most frequently citing disciplines made up $95.0 \%$ of all citations, while in human geography they accounted for $80.7 \%$ of citations.

The next aspect of relations of geography with other disciplines was determining the set of disciplines from which geography derives knowledge. As in the case of the use of geographical knowledge, this was done via an analysis of citations of works published in journals classed as belonging to the various scientific disciplines. For all works from the 28 disciplines selected, published in the years 2006-2010, the number of articles cited by geographical works was examined. The results are presented in Tables $4 \mathrm{~b}$ and 5b. Physical geography most frequently cited works from ecology, physical geography, geology, as well as geochemistry and geophysics; works in those disciplines accounted for
Table 4. Disciplines making use of the knowledge of human geography

(a) Disciplines most often citing human geography

\begin{tabular}{|r|l|r|r|}
\hline \multirow{2}{*}{ No. } & \multicolumn{2}{|c|}{ Discipline } & \multicolumn{2}{|c|}{ Articles citing } \\
\cline { 3 - 4 } & & number & \multicolumn{1}{c|}{$\%$} \\
\hline 1. & Human geography & 1,196 & 21.2 \\
2. & Ecology & 667 & 11.8 \\
3. & Economy & 573 & 10.2 \\
4. & Planning & 534 & 9.5 \\
5. & Physical geography & 407 & 7.2 \\
6. & Sociology & 347 & 6.2 \\
7. & Management science & 231 & 4.1 \\
8. & Political science & 231 & 4.1 \\
9. & Transport & 202 & 3.6 \\
10. & Remote sensing & 156 & 2.8 \\
& Remaining 18 disciplines & 1,085 & 19.3 \\
\hline & Total & 5,629 & 100.0 \\
\hline
\end{tabular}

(b) Disciplines most often cited by human geography

\begin{tabular}{|r|l|r|r|}
\hline \multirow{2}{*}{ Lp. } & \multicolumn{2}{|c|}{ Discipline } & \multicolumn{2}{c|}{ Articles cited } \\
\cline { 3 - 4 } & & number & \multicolumn{1}{c|}{$\%$} \\
\hline 1. & Human geography & 1,196 & 16.7 \\
2. & Economy & 937 & 13.1 \\
3. & Planning & 772 & 10.8 \\
4. & Ecology & 755 & 10.6 \\
5. & Sociology & 647 & 9.0 \\
6. & Political science & 477 & 6.7 \\
7. & Physical geography & 467 & 6.5 \\
8. & Management science & 273 & 3.8 \\
9. & International relations & 209 & 2.9 \\
10. & Remote sensing & 182 & 2.5 \\
& Remaining 18 disciplines & 1,240 & 17.3 \\
\hline & Total & 7,155 & 100.0 \\
\hline
\end{tabular}

Source: own compilation on the basis of the Web of Science database.

$66.5 \%$ of all articles cited. Human geography most frequently cited itself as well as works from economy, planning, and sociology, which together made up $60.2 \%$ of the articles cited. The set of those disciplines was similar to the one that cited geographical works most often. This means that each of the two geographical disciplines has a core of disciplines from which it draws knowledge, but also which reciprocate and make use of geographical knowledge. The only discipline strongly 
connected with both physical and human geography was ecology. This is not surprising if we consider that ecology studies, among other things, relations holding between man and the environment, and those are some of the basic elements of modern research problems in geography (Chojnicki 2000; Maik 2004, 2008).

Also characteristic are relations between the two geographical disciplines, which make use of each other's output, but this relation is asymmetric. Human geography refers to works in physical geography more often than the other way round. About 7\% of works cited by or citing human geography belonged to physical geography, while ca. 3\% of works cited by or citing physical geography belonged to human geography. There seems to be a tendency for human geography to cite works from natural and exact sciences generally more often than physical geography cites works from social sciences. In human geography, $27.0 \%$ of the articles it cited represented natural and exact sciences, while $5.9 \%$ of physical geography papers referred to works from social sciences. Even if we exclude works from ecology and physical geography, works from natural and exact sciences still accounted for $9.9 \%$ of all those cited by human geography. This group included remote sensing (2.5\% of the works cited), geology (1.4\%), informatics (1.3\%), mathematics (1.3\%), and soil science (1.0\%). The social science disciplines most frequently cited by physical geography included economy $(0.7 \%$ of the works cited), planning $(0.6 \%)$, and sociology $(0.5 \%)$.

To determine the intensity and complexity of links between geography and the other disciplines, use was made of Pudovkin's index characterised in the section of the article describing the research methodology. This index was used to examine bi-directional relations between the two geographical disciplines and the remaining ones, termed the strength of the relation. The bi-directionality of relations means the use of knowledge from discipline A by discipline B and the use of knowledge from disciplines $B$ by discipline
Table 5. Disciplines drawing on knowledge from physical geography

(a) Disciplines most frequently citing physical geography

\begin{tabular}{|r|l|r|r|}
\hline \multirow{2}{*}{ No. } & \multicolumn{2}{|c|}{ Discipline } & \multicolumn{2}{|c|}{ Articles citing } \\
\cline { 3 - 4 } & & number & \multicolumn{1}{c|}{$\%$} \\
\hline 1. & Ecology & 4,133 & 30.7 \\
2. & Physical geography & 1,855 & 13.8 \\
3. & Palaeontology & 1,281 & 9.5 \\
4. & Geochemistry & 1,262 & 9.4 \\
& and geophysics & & \\
5. & Geology & 1,104 & 8.2 \\
6. & Oceanography & 948 & 7.0 \\
7. & Remote sensing & 861 & 6.4 \\
8. & Human geography & 467 & 3.5 \\
9. & Biology & 446 & 3.3 \\
10. & Soil science & 446 & 3.3 \\
& Remaining 18 disciplines & 667 & 5.0 \\
\hline & Total & 13,470 & 100.0 \\
\hline
\end{tabular}

(b) Disciplines most often cited by physical geography

\begin{tabular}{|c|c|c|c|}
\hline \multirow{2}{*}{ No. } & \multirow{2}{*}{ Discipline } & \multicolumn{2}{|c|}{ Articles cited } \\
\hline & & number & $\%$ \\
\hline 1. & Ecology & 3,482 & 27.3 \\
\hline 2. & Physical geography & 1,855 & 14.5 \\
\hline 3. & Geology & 1,641 & 12.9 \\
\hline 4. & $\begin{array}{l}\text { Geochemistry } \\
\text { and geophysics }\end{array}$ & 1,505 & 11.8 \\
\hline 5. & Palaeontology & 919 & 7.2 \\
\hline 6. & Oceanography & 829 & 6.5 \\
\hline 7. & Remote sensing & 595 & 4.7 \\
\hline 8. & Soil science & 478 & 3.7 \\
\hline 9. & Biology & 427 & 3.3 \\
\hline \multirow[t]{3}{*}{10.} & Human geography & 407 & 3.2 \\
\hline & Remaining 18 disciplines & 615 & 4.8 \\
\hline & Total & 12,753 & 100.0 \\
\hline
\end{tabular}

Source: own compilation on the basis of the Web of Science database.

A. On this basis it is possible to determine the 'trade balance' of scientific knowledge, hence in the interpretation of the results obtained use was made of terms connected with economic trade, like import and export, and trade surplus or deficit. For example, 'import' in the relations of physical geography with geology means the use of geological knowledge by geography (as expressed 
by relatively frequent citations of geological works in geographical articles, taking into consideration the size of the disciplines), while 'export' means the use of geographical knowledge by geology (as expressed by relative citation rates of geographical works in geological articles, taking into consideration the size of the disciplines). A favourable 'trade balance' means that 'exports' dominate over 'imports', i.e. that geology takes greater advantage of geographical knowledge than physical geography of geological knowledge. And the other way round, an adverse 'trade balance' means the dominance of 'imports' over 'exports', i.e. that physical geography derives more knowledge from geology than geology from geography.

In the analysis, values of the index of the strength of the relation of geography with other disciplines under 10 were taken to be low, between 10 and 30, average, and over 30, high. It should be stressed that establishing a uniform interpretation is fairly difficult because of differences between the geographical disciplines. In physical geography the average strength of the relation was 15.5 (the median 2.5; standard deviation 25.6), in human geography, 25.7 (the median 11.7; standard deviation 36.8), and for the whole of geography, 20.6 (the median 5.1; standard deviation 31.9 ). Readily visible are differences in the values for the individual disciplines.

The relations of human geography with other disciplines are presented in Figure 1. It shows them to be the strongest with social sciences, especially with planning, regional studies and demography, although there are disciplines in natural and exact sciences with which this relation is also strong (e.g. with physical geography and remote sensing). Predominant in the relations with social sciences are 'deficits' in the scientific 'trade balance', which means that human geography makes more frequent use of the output of other

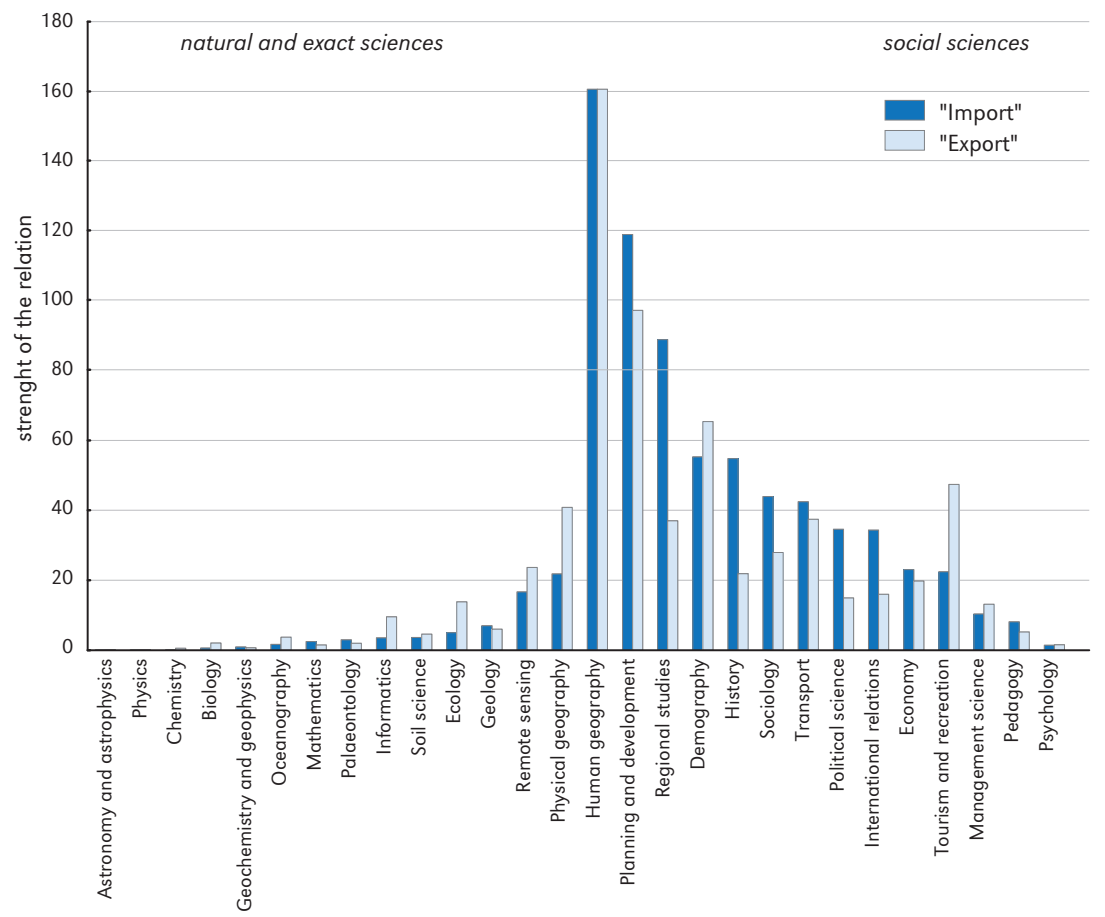

Figure 1. Relations of human geography with other disciplines

Source: own compilation on the basis of the Web of Science database. 
sciences than the other way round. The disciplines with which human geography has the most adverse 'trade balance' include regional studies, history and planning, and the most favourable 'trade balance', with tourism and recreation, ecology, and physical geography, of which the last two are classed as natural and exact sciences.

Relations of physical geography with other disciplines are presented in Figure 2. As in the case of human geography, there is a predominance of 'deficits' on its scientific trade, which means that physical geography makes more frequent use of the output of the other sciences. The disciplines with which physical geography has the most adverse 'trade balance' include geology, palaeontology and human geography, while its most favourable 'trade balance' is with ecology, remote sensing, biology, and informatics.

The analysis conducted supplies some arguments in the discussion of the dichotomy of geography (e.g. Lisowski 1996; Maik 2004, 2008), because relations with other disciplines are in many cases stronger than between the geographical disciplines. The strength of the bi-directional relation of human geography with physical geography is 31.3 , much weaker than its links with planning (108.0), regional studies (62.9), demography $(60,3)$, transport sciences (39.9), history (38.3), sociology (36.0), and tourism and recreation (34.9). The situation is similar in the case of physical geography: its relations with palaeontology (94.9), geology (69.7) and remote sensing (45.5) are stronger than with human geography. Generally, the relations of human geography with social sciences are stronger than those of physical geography with natural and exact sciences, as Table 6 shows. The latter make more frequent use of the output of human geography than social sciences of the output of physical geography. The 'trade balance' in the relation between the two geographical disciplines is in favour of human geography, which means that it makes more frequent use of the output of physical geography than the other way round. Both geographies also rely on their own works, with the proportion of citations of a discipline's own works in the total number of the articles cited in it being higher in human geography (15.3\%) than in physical geography (8.7\%). This means that geography

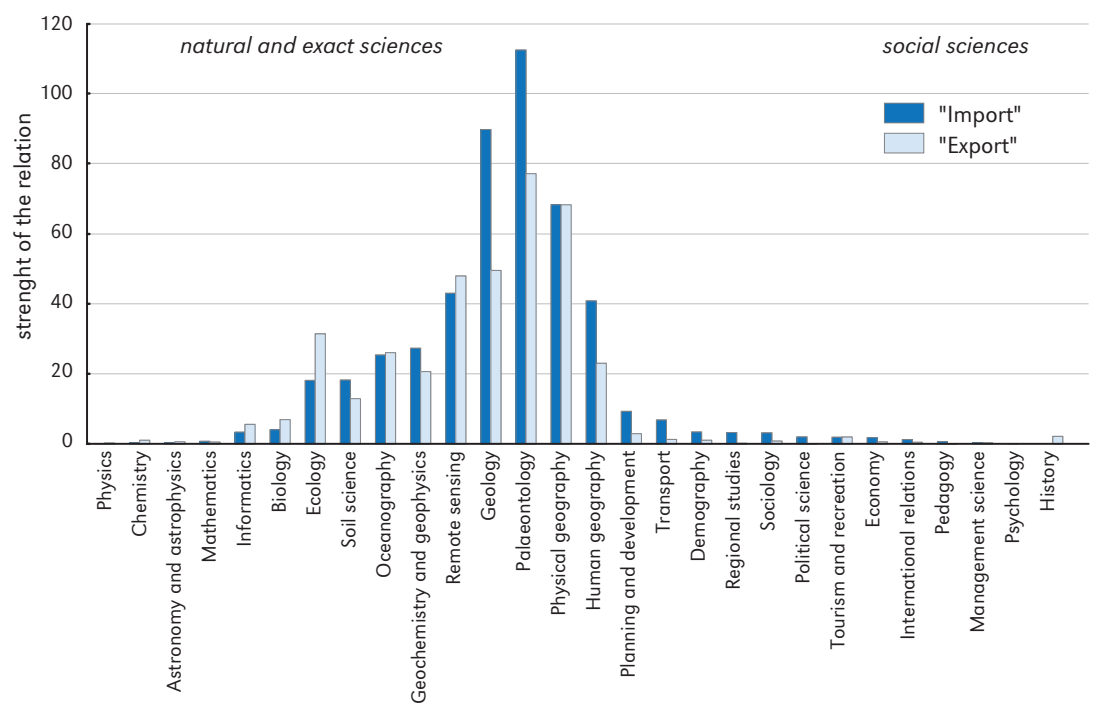

Figure 2. Relations of physical geography with other disciplines

Source: own compilation on the basis of the Web of Science database. 
Table 6. Average strength of the relation of geography with other disciplines (mean value of Pudovkin's index)

\begin{tabular}{|l|c|c|c|c|}
\hline \multirow{2}{*}{ Group of disciplines } & \multicolumn{2}{|c|}{ Physical geography } & \multicolumn{2}{c|}{ Human geography } \\
\cline { 2 - 5 } & 'import' & 'export' & 'import' & 'export \\
\hline Natural and exact sciences & 29.4 & 24.9 & 4.7 & 7.8 \\
Natural and exact sciences & 26.4 & 21.6 & 3.4 & 5.2 \\
(without physical geography) & & & & \\
Social sciences & 5.3 & 2.4 & 49.9 & 40.4 \\
Social sciences & 2.6 & 0.9 & 41.4 & 31.1 \\
(without human geography) & & & & \\
\hline
\end{tabular}

Source: own compilation.

makes relatively little use of its own output. By comparison, in other disciplines such self-citation rates are: astronomy and astrophysics, 74.4\%; economy, 52.4\%; chemistry, $35.4 \%$; ecology, $32.9 \%$; pedagogy $32.5 \%$; geochemistry, 30.0\%; and history, 29.8\%.

\section{Summing up and conclusions}

The conducted analysis of relations of geography with other disciplines can be summed up as follows:

1. The position of geography among other disciplines as measured by the impact factor of scientific journals is not as low as can be supposed. The relative position of human geography in social sciences is higher than that of physical geography in natural and exact sciences, although works of the latter are generally cited more often.

2. Both geographical disciplines show an adverse 'trade balance' in scientific exchange, which means that they make more frequent use of knowledge from other disciplines than the other way round.

3. Human geography is more 'introverted', which means that it cites its own works more often than physical geography. Even so, the use of a discipline's own works is low in geography as a whole when compared with other disciplines.

4. In human geography relations with other disciplines are stronger and link it with a greater number of disciplines than in the case of physical geography. Also, human geography draws on the output of natural and exact sciences more often than physical geography does on that of social sciences.

5. In internal relations physical geography 'imports' more from of human geography than it 'exports' to it.

The above conclusions largely corroborate those reached by Laffan (2010), who, using a similar research procedure, also showed that human geography and physical geography were characterised by an adverse 'trade balance' in scientific exchange, and that human geography displayed higher 'introversion'.

Finally, it is worth remembering that one should be careful in the interpretation of the results, for several reasons, of which two seem to be the most significant. First, the results of the analysis of the relations of geography with other sciences presented in this article, like the earlier empirical studies in this field, concern primarily world geography, which is dominated by American and British geographers. As those earlier works have shown, the proportion of authors from English-speaking countries in the journals indexed in the Web of Science database usually varies between 70\% and 90\% (e.g. Guttiérrez \& López-Nieva 2001; Foster et al. 2007; Bański \& Ferenc 2013). The situation of geography in Poland and other countries can differ from the one presented here, depending on the relations between individual disciplines specific to each national system of sciences that have formed over a long period of time.

Secondly, the analysis revealed that this type of research has to face some challenges. 
Among them are different citation mechanisms operating in social and natural sciences, hence also in human geography and physical geography. In social sciences the diffusion of knowledge is slower than in natural ones. For example, in the case of articles from physics the first citations appear already a month or two after their publication, while for works in economy, sociology or human geography this period is a few years, with a citation peak sometimes a decade or several decades after the publication (Foster et al. 2007). Besides, our analysis rested on articles published in scientific journals and did not consider other modes of scholarly communication. But in social sciences monographs play a greater role in communicating research results than in natural sciences.

Irrespective of those challenges, it seems that this type of research can supply arguments in the discussion about the state and

\section{References}

Aalbers M.B., 2004. Creative destruction through the Anglo-American hegemony: A non-Anglo American view on publications, referees and language. Area, vol. 36, no. 3, pp. 319-322.

Aalbers M.B., Rossi U., 2006. Beyond the AngloAmerican hegemony in human geography: A European perspective. GeoJournal. Vol. 67, no. 2, pp. 137-147.

Aalbers M.B., Rossi U., 2009. Anglo-American/Anglophone hegemony [in:] R. Kitchin, N. Thrift (eds.), International Encyclopedia of Human Geography vol. 1, New York: Elsevier, pp. 116-121.

Archambault É., Vignola-Gagne É., Coté G., LAREVIère V., GINGRAS Y., 2006. Benchmarking scientific output in the social sciences and humanities: The limits of existing databases. Scientometrics, vol. 68, no. 3, pp. 329-342.

Bajerski A., 2008a. Polskie czasopisma geograficzne w bazie Scopus: Próba analizy komunikacji naukowej w polskiej geografii. Czasopismo Geograficzne, vol. 79, no. 3, pp. 367-382. development of geography, also Polish geography. Especially so that one can observe discrepancies between objective indices and subjective assessments of the role and position of geography in the system of sciences. Hence it would be desirable to continue this type of analysis and improve methods of studying relations of geography with other disciplines, as well as those between the two geographical disciplines: physical and human.

\section{Acknowledgement}

This research was supported financially by the National Science Centre on the basis of decision no. DEC-2011/03/D/HS4/01662.

\section{Editors' note:}

Unless otherwise stated, the sources of tables and figures are the authors', on the basis of their own research.

BAJERSKI A., 2008b. Ranking ośrodków geografii społeczno-ekonomicznej w Polsce na podstawie cytowań w bazach Web of Science. Przegląd Geograficzny, vol. 80, no. 4, pp. 579-589.

BAJERSKI A., 2011. The role of French, German and Spanish journals in the scientific communication in international geography. Area, vol. 43, no. 3, pp. 305-313.

BAJerSKI A., SIWEK T., 2012. Bibliometrická analýza české geografie v databázi Scopus. Geografie, vol. 117, no. 1, pp. 52-71.

BAŃSKI J., 2010. Stan krytyczny polskiej geografii - krytyka stanu. Przegląd Geograficzny, vol. 82, no. 3, pp. 319-333.

BAŃSKI J., 2013. Dlaczego geografia jest w "B" - kilka uwag zwiqzanych z ostatniq kategoryzacja jednostek naukowych. Przegląd Geogaficzny, vol. 85, no. 4, pp. 677-682.

BAŃSKI J., Ferenc M., 2013. "International" or "Anglo-American" Journals of Geography? Geoforum, 45, pp. 285-295.

BAR-ILAN J., 2008. Which h-index? - A comparison of WoS, Scopus and Google Scholar. Scientometrics, vol. 74, no. 2, pp. 257-271. 
Bodman A.R., 1991. Weavers of ifluence: The structure of contemporary geographic research. Transactions of the Institute of British Geographers, New Series, vol. 16, no. 1, pp. 21-37.

Bunge M., 1998. Philosophy of science, volume 1: From problem to theory. New Brunswick: Transaction Publishers.

ChOJNICKI Z., 1999. Podstawy metodologiczne $i$ teoretyczne geografii. Poznań: Bogucki Wydawnictwo Naukowe.

CHOJNICKI Z., 2000. Perspektywiczne problemy badawcze geografii [in:] B. Kortus, A. Jackowski, K. Krzemień (eds.), Nauki geograficzne w poszukiwaniu prawdy o ziemi i człowieku. Kraków: Instytut Geografii Uniwersytetu Jagiellońskiego, pp. 151-157.

FERGUSON R.I., 2003. Publication practices in physical and human geography: A comment on Thrift's 'The future of geography'. Geoforum, vol. 34 , no. 1, pp. 9-11.

Foster J., Muellerleile C., Olds K., PeCK J., 2007. Circulating economic geographies: Citation patterns and citation behaviour in economic geography, 1982-2006. Transactions of the Institute of British Geographers, vol. 32, no. 3, pp. 295-312.

FranCESChet M., 2010. A comparison of bibliometric indicators for computer science scholars and journals on Web of Science and Google Scholar. Scientometrics, vol. 83, no. 1, pp. 243-258.

Guttiérrez J., López-Nieva P., 2001. Are international journals of human geography really international? Progress in Human Geography, vol. 25 , no. 1, pp. 53-69.

HASSINK R., 2007. It's the language, stupid! On emotions, strategies, and consequences related to the use of one language to describe and explain a diverse world. Environment and Planning A, vol. 39, no. 6, pp. 1282-1287.

JOHNSTON R., 2005. Geography - coming apart at the seams? [in:] N. Castree, A. Rogers, D. Sherman (eds.), Questioning geography. Fundamental debates, Malden-Oxford: Blackwell, pp. 9-25.

LAFFAN S.W., 2010. The citation relationships between journals of geography and cognate disciplines. Geographical Research, vol. 48, no. 2, pp. 166-180.

LISOWSKI A., 1996. Tendencje dezintegracyjne $i$ integracyjne we wspótczesnej geografii człowieka. Przegląd Geograficzny, vol. 69, no. 3-4, pp. 318-333.

LIsOWSKI A., 2004. Geografia społeczno-ekonomiczna a nauki społeczne [in:] Z. Chojnicki (ed.), Geografia wobec problemów teraźniejszości i przyszłości, Poznań: Bogucki Wydawnictwo Naukowe, pp. 67-80.

LISOWSKI A., 2008. W poszukiwaniu integracji przedmiotowej i tożsamości geografii na poczatku XXI w. [in:] S. Liszewski, J. Łoboda, W. Maik (eds.), Stan i perspektywy rozwoju geografii w Polsce, Bydgoszcz: Wydawnictwo Uczelniane Wyższej Szkoły Gospodarki w Bydgoszczy, pp. 43-52.

LISOWSKI A., 2011. Geography and social sciences in transdisciplinary science. Miscellanea Geographica, 15, pp. 9-40.

Malk W., 2004. Główne płaszczyzny relacji między geografia fizyczna a geografia społeczno-ekonomiczna [in:] Z. Chojnicki (ed.), Geografia wobec problemów teraźniejszości i przyszłości, Poznań: Bogucki Wydawnictwo Naukowe, pp. 9-24.

MaIK W., 2008. Aktualne problemy rozwoju geografii w świetle jedności i tożsamości dyscypliny [in:] S. Liszewski, J. Łoboda, W. Maik (eds.), Stan i perspektywy rozwoju geografii w Polsce, Bydgoszcz: Wydawnictwo Uczelniane Wyższej Szkoły Gospodarki w Bydgoszczy, pp. 27-38.

MIKKI S., 2010. Comparing Google Scholar and ISI Web of Science for earth sciences. Scientometrics, vol. 82, no. 2, pp. 321-331.

MinCA C., 2000. Venetian geographical praxis. Environment and Planning D, vol. 18, no. 3, pp. 285-289.

Mingers J., LipitAKIS E.A.E.C.G., 2010. Counting the citations: A comparison of Web of Science and Google Scholar in the field of business and management. Scientometrics, vol. 85, no. 2, pp. 613-625

Mulligan G.F., 2003. What's wrong with economic geography? Other thoughts on the rift. Canadian Journal of Regional Science, vol. 26, no. 1, pp. 33-37.

Pudovkin A. I., 1993. Citation relationships among marine biology journals and those in related field. Marine Ecology Progress Series, 100, pp. 207-209.

PudOVkin A. I., Fuseler E.A., 1995. Indices of journal citation relatedness and citation relationships 
among aquatic biology journal. Scientometrics, vol. 32, no. 3, pp. 227-236.

Pudovkin A.I., Garfield E., 2002. Algorithmic procedure for finding semantically related journal. Journal of the American Society for Information Science and Technology, vol. 53, no. 13, pp. 1113-1119.

RACKI G., 2003. Polskie czasopisma geograficzne a międzynarodowy obieg informacji naukowej. Przegląd Geograficzny, vol. 75, no. 1, pp. 101-119.

RichuING A., 2008. Jednosć geografii jako podstawowy warunkek istnienia dyscypliny [in:] S. Liszewski, J. Łoboda, W. Maik (eds.), Stan i perspektywy rozwoju geografii w Polsce, Bydgoszcz: Wydawnictwo Uczelniane Wyższej Szkoły Gospodarki w Bydgoszczy, pp. 39-42.

Schuermans N., Meeus B., De Maesschalck F., 2010. Is there a world beyond the Web of Science? Publication practices outside the heartland of academic geography. Area, vol. 42, no. 4, pp. 417-424.

ShORT J.R., BONICHE A., KIM Y., LI LI P., 2001. Cultural globalization, global English, and geography journals. Professional Geographer, vol. 53, no. 1, pp. 1-11.

SimOnSEN K., 2004. Differential spaces of critical geography. Geoforum, vol. 35, no. 2, pp. 525-528.

ŚlesZYŃSKI P., 2009. Pozycja polskich czasopism i serii geograficznych w świetle baz Google Scholar. Przeglad Geograficzny, vol. 81, no. 4, pp. 551-576.

ŚLESZYŃSKI P., 2013a. Cytowania polskich czasopism naukowych z zakresu geografii i badań regionalnych po 1990 r., Studia Regionalne i Lokalne, vol. 2013, no. 3, pp. 75-88.

ŚLESZYŃSKI P., 2013b. Cytowania i oddziaływanie polskich ośrodków geograficznych według Google Scholar. Przegląd Geograficzny, vol. 85, no. 4, pp. 599-627.
ŚLESZYŃSKI P., 2014. 50 years of Geographia Poloni$c a$ in the light of citations. Geographia Polonica, vol. 87, no. 1, pp. 143-155.

THRIFT N., 2002. The future of geography. Geoforum, vol. 33, no. 3, pp. 291-298.

TIMÁR J., 2004. More than 'Anglo-American', it is 'Western': Hegemony in geography from Hungarian perspective. Geoforum, vol. 35, no. 2, pp. 533-538.

Turner B.L., 2002. Contested identities: Humanenvironment geography and disciplinary implications in a restructuring Academy. Annals of the Association of American Geographers, vol. 92, no. 1, pp. 52-74.

Ward K., Johnston R., Richards K., Gandy M., Taylor Z., Paasi A., Fox R., Serue M., Wal-chung Yeung H., Barnes T., Blunt A., McDowell L., 2009. The future of research monographs: An international set of perspectives. Progress in Human Geography, vol. 33, no. 1, pp. 101-126.

Whitehand J.W.R., 1985. Contributors to the recent development and influence of human geography: What citation analysis suggests. Transactions of the Institute of British Geographers, New Series, vol. 10, no. 2, pp. 222-234

VieiRA E.S., Gomes J.A.N.F., 2009. A comparison of Scopus and Web of science for a typical university. Scientometrics, vol. 81, no. 2, pp. 587-600.

YeUNG H.W., 2001. Redressing the geographical bias in social science knowledge. Environment and Planning A, vol. 33, no. 1, pp. 1-9.

YITZHAKI M., 1998. The 'language preference' in sociology: Measures of 'language self-citation', 'relative own-language preference indicator', and 'mutual use of languages'. Scientometrics, vol. 41, no. 1-2, pp. 243-254.
(C) Krzysztof Stachowiak • Artur Bajerski

(C) Geographia Polonica

(C) Institute of Geography and Spatial Organization

Polish Academy of Sciences - Warsaw • 2016
Article first received • November 2015 Article accepted • March 2016 